\title{
Preparation, Characterization and Comparison of In-Vitro Dissolution Data of Montelukast Sodium Tablet with the RLD Product
}

\author{
Tushar Saha ${ }^{1 *}$ and Md Abdullah Al Mizan ${ }^{1}$ \\ ${ }^{1}$ Department of Pharmaceutical Technology, University of Dhaka, Bangladesh
}

*Corresponding author: Tushar Saha, Department of Pharmaceutical Technology, Faculty of Pharmacy, University of Dhaka, Dhaka-1000, Bangladesh

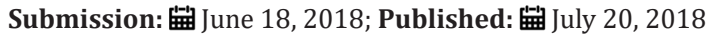

\begin{abstract}
The aim of the present investigation was to prepare and characterize montelukast sodium tablet and then compare the in vitro dissolution data with RLD product. Wet granulation technology was applied for both intra and extra granular part of the tablet. Physicochemical properties of the tablet were performed according to the official method of pharmacopoeia and obtained result was satisfactory. The f2 values of in vitro dissolution study was found after 45 minutes were 53.16 in $0.5 \%$ SLS medium, 70.17 in $0.1 \mathrm{~N} \mathrm{HCl}$ medium (pH 1.2), 99 in acetate buffer medium (pH 4.5) and 82.73 in phosphate buffer (pH 6.8). From the obtained $\mathrm{f} 2$ value it was clear that, prepared montelukast sodium tablet was satisfactory in case of dissolution as it was over 50 in every medium.
\end{abstract}

Keywords: Montelukast sodium; RLD product; f2 value

\section{Introduction}

Montelukast sodium is widely used in the treatment of asthma, rhinitis, arthritis as well as heart attack [1,2]. It is a selective antagonist of leukotriene receptor and can be used to lower the blood pressure [3]. Generally, Montelukast is used as the sodium salt although the doses are expressed in terms of base. The usual dose of Montelukast Sodium is 10.37 or $10.40 \mathrm{mg}$ which is equivalent to $10 \mathrm{mg}$ of Montelukast [4]. It is hard to formulate new generic and this why pharmaceutical companies mimic the innovator products. Among all criteria, dissolution profile acceptance is one of the main and major issues. It is needed to meet the dissolution data with the Reference Listed Drug (RLD). RLD is mainly innovator product and termed as Brand and marketed with full dossier [5]. RLD is mainly listed in Orange Book. According to FDA if the $\mathrm{f} 2$ value of dissolution is 50 or than 50 then it is considered as similar of two products.

On the basis of this, an attempt was made to formulate the Montelukast Sodium tablet and characterize its physico chemical properties and mainly to check out the similarity factor of dissolution (f2 value) with the RLD. A series of formulation was trialed but only the best formula was proposed here.

\section{Materials and Method}

Montelukast sodium was obtained from Incepta Pharmaceuticals Ltd, Bangladesh as gift sample. Other chemicals and materials used in this experiment were of analytical grade.

\section{Preparation of Montelukast Sodium Tablet}

Montelukast Sodium tablet was prepared by wet granulation technique. Composition of tablet with intra-granular part, granulating fluid and extra-granular part was tabulated in Table 1.

Table 1: Formulation of Prepared Montelukasr Sodium Tablet.

\begin{tabular}{|c|c|}
\hline \multicolumn{2}{|c|}{ Intra-granular Part } \\
\hline Montelukast Sodium & $10.40 \mathrm{mg}$ \\
\hline Lactose Monohydrate (plain) & $89.40 \mathrm{mg}$ \\
\hline Microcrystalline Cellulose-101 & $80.20 \mathrm{mg}$ \\
\hline Crosscarmellose Sodium & $6.00 \mathrm{mg}$ \\
\hline Hydroxypropylcelluose & $1.00 \mathrm{mg}$ \\
\hline Granulating Fluid & $1.00 \mathrm{mg}$ \\
\hline Hydroxypropylcelluose & $84.00 \mathrm{mg}$ \\
\hline Purified Water & $10.00 \mathrm{mg}$ \\
\hline Extra-granular Part & $2.00 \mathrm{mg}$ \\
\hline Crosscarmellose Sodium & $200.00 \mathrm{mg}$ \\
\hline Magnesium Stearate &
\end{tabular}




\section{Preparation of dissolution media}

For dissolution, four media were prepared which were $0.5 \%$ SLS media, $0.1 \mathrm{~N} \mathrm{HCl} \mathrm{(pH} \mathrm{1.2)} \mathrm{media,} \mathrm{acetate} \mathrm{buffer} \mathrm{(pH} \mathrm{4.8)} \mathrm{media}$ Results and Discussion

\section{Physicochemical Properties of Montelukast Sodium Tablet}

Table 2: Physicochemical Properties of Prepared Montelukasr Sodium Tablet.

\begin{tabular}{|c|c|c|c|}
\hline Avg. Weight of Tablet (mg) & Avg. Hardness (KP) & Friability (\%) & Assay of Core Tablet \\
\hline 202.17 & 13.25 & 0.13 & 102.54 \\
\hline
\end{tabular}

Physicochemical properties of prepared Montelukast Sodium with-in the range of pharmacopeia limit. Again, average weight of were presented in Table 2. Friability and assay of core tablet was tablet was uniform and average hardness was satisfactory.

Dissolution Profile of RLD Product and Prepared Montelukast Sodium Tablet

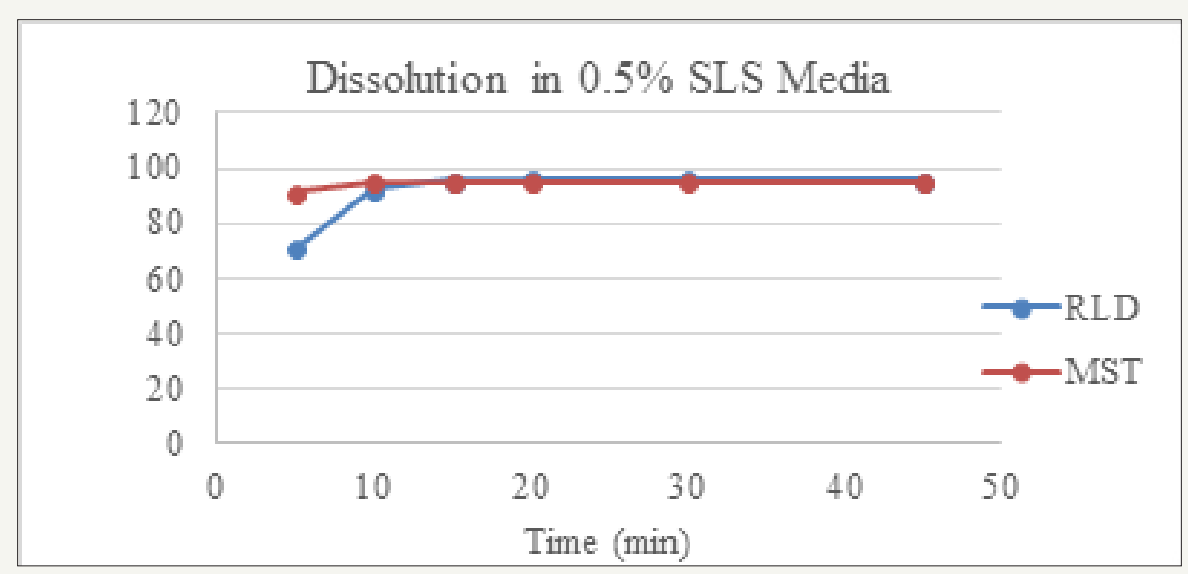

Figure 1: Dissolution of RLD and MST in 0.5\% SLS Media.

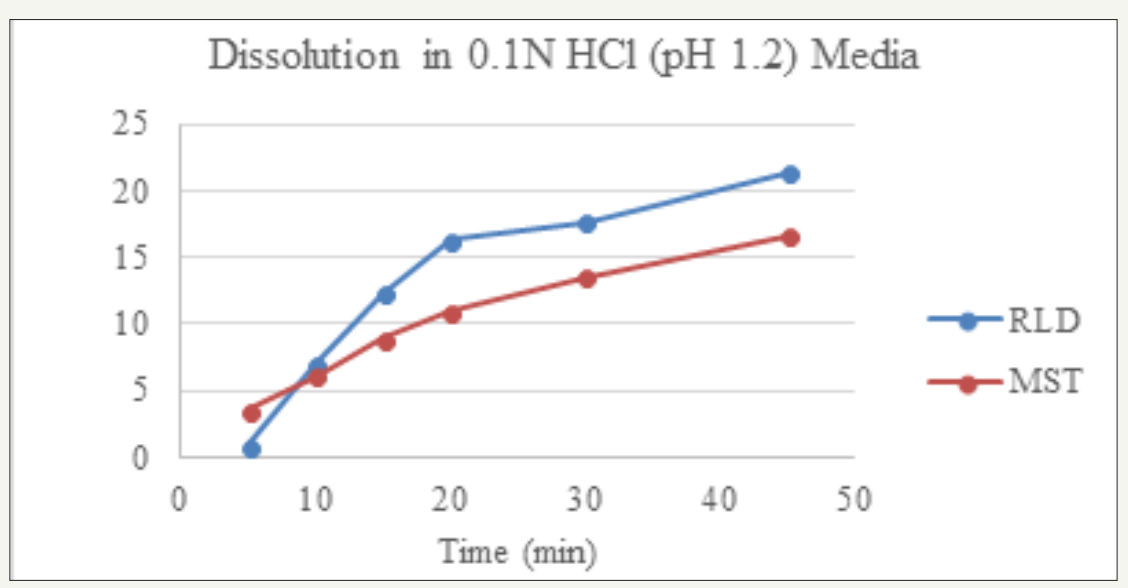

Figure 2: Dissolution of RLD and MST in $0.1 \mathrm{~N} \mathrm{HCl} \mathrm{(pH} \mathrm{1.2)} \mathrm{Media.}$

Table 3: Dissolution Profile of RLD and Prepared Montelukast Sodium Tablet (MST).

\begin{tabular}{|c|c|c|c|c|c|c|c|c|}
\hline $\begin{array}{c}\text { Dissolution } \\
\text { Media }\end{array}$ & Code & $5 \mathrm{~min}$ & $10 \mathrm{~min}$ & $15 \mathrm{~min}$ & $20 \mathrm{~min}$ & $30 \mathrm{~min}$ & $45 \mathrm{~min}$ & f2 value \\
\hline \multirow{2}{*}{$0.5 \%$ SLS media } & RLD & 70.83 & 92.29 & 95.74 & 96.35 & 96.09 & 95.74 & \multirow{2}{*}{53.16} \\
\hline & MST & 91.62 & 94.90 & 95.16 & 95.28 & 95.03 & 94.94 & \\
\hline \multirow[t]{2}{*}{$0.1 \mathrm{~N} \mathrm{HCl}$ media } & RLD & 0.86 & 7.04 & 12.33 & 16.28 & 17.64 & 21.39 & \multirow{2}{*}{70.17} \\
\hline & MST & 3.48 & 6.13 & 8.91 & 10.89 & 13.51 & 16.59 & \\
\hline
\end{tabular}




\begin{tabular}{|c|c|c|c|c|c|c|c|c|}
\hline \multirow{2}{*}{$\begin{array}{c}\text { Acetate buffer media } \\
\text { (pH 4.5) }\end{array}$} & RLD & 0 & 0 & 0 & 0 & 0.03 & 0 \\
\cline { 2 - 8 } & MST & 0.08 & 0.08 & 0.09 & 0.11 & 0.1 & 0.07 \\
\hline $\begin{array}{c}\text { Phosphate buffer media } \\
(\mathrm{pH} \mathrm{6.8)}\end{array}$ & RLD & 0.05 & 0.26 & 0.25 & 0.36 & 0.25 & 0.31 \\
\cline { 2 - 9 } & MST & 0.75 & 1.76 & 2.18 & 2.44 & 2.34 & 2.25 \\
\hline
\end{tabular}

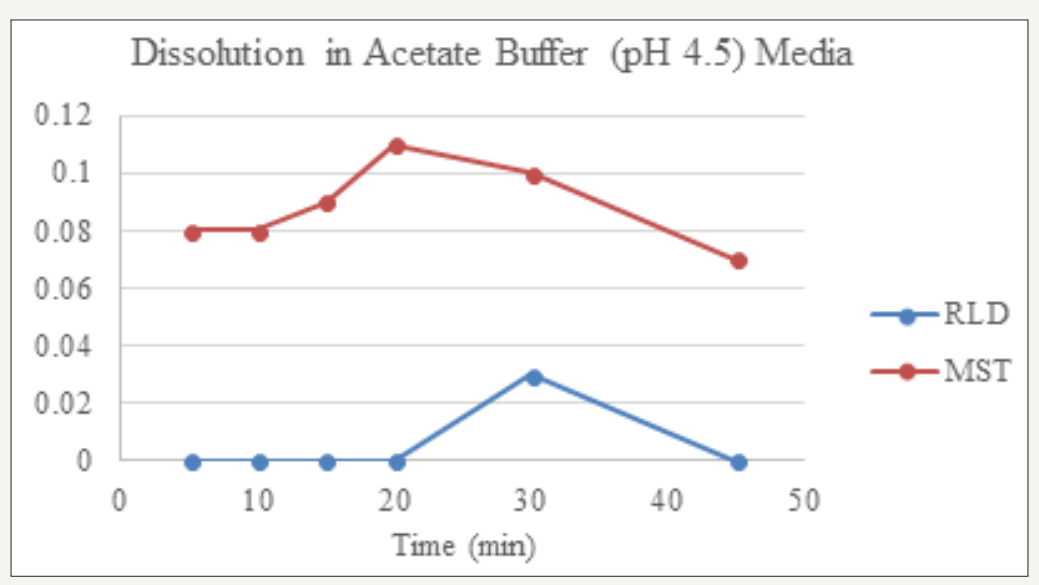

Figure 3: Dissolution of RLD and MST in Acetate Buffer ( $\mathrm{pH} 4.5$ ) Media.

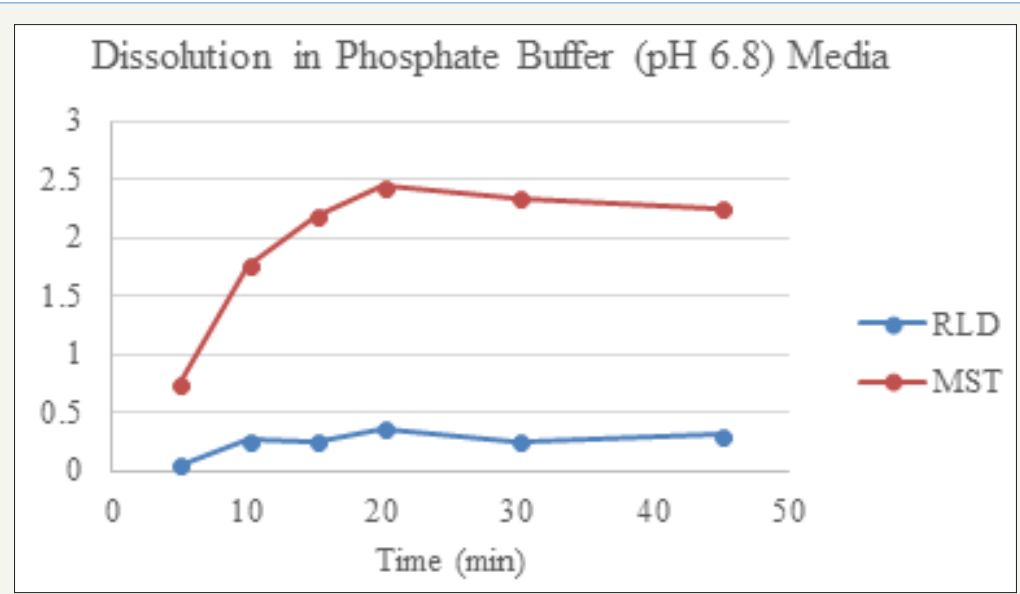

Figure 4: Dissolution of RLD and MST in Phosphate Buffer (pH 6.8) Media.

Dissolution profile of Montelukast Sodium tablet with RLD was tabulated and presented in Table 3 and (Figures 1-4). From the result, it is obvious that, prepared montelukast sodium tablet met the similarity factor as in every media; the value of $\mathrm{f} 2$ was more than 50 after 45 minutes of dissolution time.

\section{Conclusion}

A successful formulation of Montelukast Sodium was made as it met all the criteria of pharmacopoeia and FDA set similarity factor value of dissolution. Further studies have to be done for other parameters set by the authority for NDA, ANDA and other submission.

\section{References}

1. Wang D, Zhou C, Cong R, Li Y, Wang X (2017) Simultaneous determination of Montelukast sodium Senantiomer and A5 enantiomers in Montelukast sodium bulk drug by normal phase chiral HPLC. Indian J Pharm Sci 79(1): 139-148

2. Walia M, Lodha R, Kabra SK (2006) Montelukast in pediatric asthma management. Indian J Pediatr 73(4): 275-282.

3. Bithi FA, Saha T, Ahmed N, Hasan I, Reza MS (2017) Preparation and In vitro evaluation of mucoadhesive tablets of montelukast sodium. 20(2): 123-131.

4. Zhao JJ, Rogers JD, Holland SD, Larson P, Amin RD (1997) Pharmacokinetics and bioavailability of montelukast sodium (MK-0476) in healthy young and elderly volunteers. Biopharm Drug Dispos 18(9): 769-777.

5. Prachi G, Shah DB, Dilip M (2015) Comparative study of reference products in generic drug development in us and Europe. International Journal of Recent Scientific Research 6(3): 3113-3119. 
(c) (i) Creative Commons Attribution 4.0 International License

For possible submissions Click Here

Submit Article

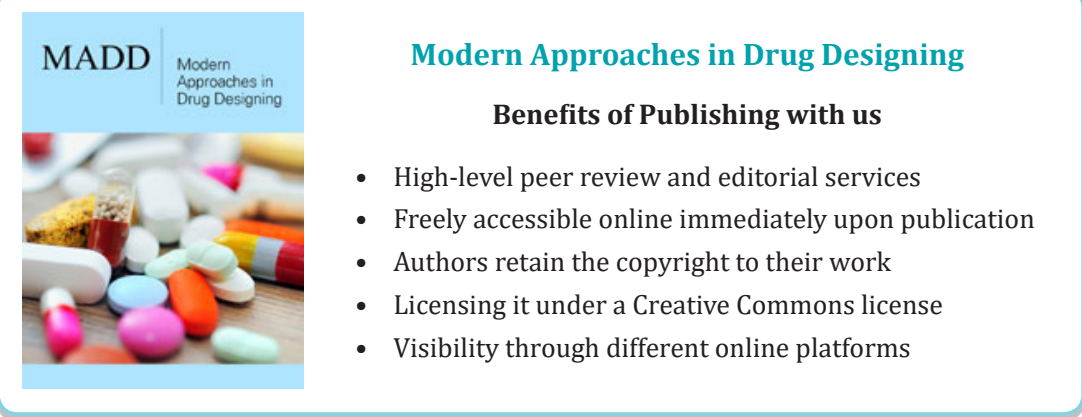

